\title{
Sintesis Karbon Aktif Tempurung Ketapang (Terminalia catappa) Sebagai Adsorben Minyak Jelantah
}

\author{
Megiyo $^{1}$, Herman Aldila $^{1 *}$, Fitri Afriani ${ }^{1}$, Robby Gus Mahardika ${ }^{2}$, Sito Enggiwanto ${ }^{2}$ \\ ${ }^{1)}$ Jurusan Fisika, Fakultas Teknik, Universitas Bangka Belitung \\ ${ }^{2)}$ Jurusan Kimia, Fakultas Teknik, Universitas Bangka Belitung \\ Jl. Kampus Peradaban, Merawang, Bangka, 33172 \\ *) Email: herman-aldila@ubb.ac.id
}

\begin{abstract}
Activated carbon is the most common adsorbents used in regeneration of cooking oil process. Waste frying oil is a residual of frying that has been destructed due to repeated use. For reusable, it must through by oil regeneration process to eliminate impurities and free radicals. One of the abundant biomass and feasible to be activated carbon is ketapang shell. The synthesis of activated carbon used activator $\mathrm{H}_{2} \mathrm{SO}_{4} 11 \%$ with ratio $1: 4(\mathrm{w} / \mathrm{v})$ followed by thermal activation at $650^{\circ} \mathrm{C}$ for 2 hours. Activated carbon is then mixed with waste frying oil with variations of $5 \%, 7.5 \%$ and $10 \%$ and is left for 24 hours. As an antioxidant to free radicals added extract iding-iding (Stenochlaena palustris) of 5\%. Based on the observation data SEM pore distribution on activated charcoal fairly evenly with the average pore width around $10 \mu \mathrm{m}$. The results of acid number and free fatty acid test showed that the greater amount of activated carbon used, the value of acid number and free fatty acid content will decrease. The optimum condition was obtained on $10 \%$ active carbon and $5 \%$ extract with $0.8 \%$ acid value and $0.78 \%$ free fatty acid content.
\end{abstract}

Keywords: Activated carbon, waste frying oil, adsorbent

\begin{abstract}
Abstrak: Karbon aktif merupakan salah satu adsorben yang umum digunakan dalam upaya peningkatan regenerasi minyak jelantah. Minyak jelantah merupakan limbah hasil sisa penggorengan yang telah terdestruksi akibat pemakaian yang berulang-ulang. Untuk dapat digunakan kembali minyak jelantah harus mengalami proses regenerasi minyak untuk menghilangkan impuritas dan radikal bebas. Salah satu biomassa yang begitu melimpah dan layak untuk dijadikan karbon aktif adalah tempurung ketapang. Sintesis karbon aktif tempurung ketapang dilakukan dengan menggunakan aktivator $\mathrm{H}_{2} \mathrm{SO}_{4} 11 \%$ dengan perbandingan 1:4 (b/v) dilanjutkan dengan aktivasi termal pada temperatur $650^{\circ} \mathrm{C}$ selama 2 jam. Karbon aktif yang diperoleh kemudian dicampurkan dengan minyak jelantah dengan variasi $5 \%, 7,5 \%$ dan $10 \%$ dan dibiarkan selama 24 jam. Sebagai penangkal radikal bebas ditambahkan ekstrak iding-iding (Stenochlaena palustris) sebesar 5\%. Berdasarkan hasil pengamatan data SEM sebaran pori pada arang aktif tempurung ketapang cukup merata dengan lebar pori rata-rata berkisar $10 \mu \mathrm{m}$. Hasil uji bilangan asam dan kadar asam lemak bebas menunjukkan bahwa semakin besar jumlah karbon aktif yang digunakan maka nilai bilangan asam dan kadar asam lemak bebas akan semakin menurun. Kondisi optimum diperoleh pada komposisi $10 \%$ karbon aktif dan 5\% ekstrak iding-iding dengan nilai bilangan asam $0,8 \%$ dan kadar asam lemak bebas $0,78 \%$.
\end{abstract}

Kata kunci: Karbon aktif, minyak jelantah, adsorben.

\section{Pendahuluan}

Karbon aktif merupakan material amorf yang dihasilkan dari material-material yang mengandung karbon dan memiliki permukaan dalam (internal surface) sehingga memiliki afinitis tinggi untuk menyerap berbagai material tertentu (Purnomo, 2010). Sifat adsorpsi karbon aktif dipengaruhi oleh beberapa faktor diantaranya: ukuran partikel impuritas, temperatur, derajat keasaman $(\mathrm{pH})$ dan waktu kontak (Halimah, 2016). Umumnya karbon 
aktif dihasilkan melalui proses modifikasi arang yang berbentuk padatan porus yang mengandung 85-95\% karbon. Untuk menghilangkan kandungan air dan komponen-komponen volatil dari material-material yang mengandung karbon dilakukan proses pembakaran arang yang telah diaktivasi pada suhu tinggi (Sembiring \& Sinaga, 2003). Komponen dari arang ini terdiri dari karbon terikat (fixed carbon), abu, air, nitrogen dan sulfur serta memiliki porus yang masih tertutup oleh hidrokarbon, tar dan senyawa organik lainnya (Djatmiko \& Widjaja, 1985). Kualitas arang juga dapat ditentukan dari beberapa aspek seperti ukuran (batangan, serbuk halus dan pecahan), warna, tingkat kekerasan, tingkat kerapuhan, berat jenis, kadar air, kadar abu, dan kemurniannya (Fauziah, 2009). Pada umumnya luas permukaan karbon aktif berkisar 3000-3500 mg/g dan memilki daya serap sebesar $25-100 \%$ dari berat karbon aktif itu sendiri (Kirk \& Othmer, 1992).

Minyak jelantah merupakan salah satu limbah hasil penggunaan minyak goreng secara berulang-ulang. Akibatnya minyak tersebut akan mengalami destruksi yang apabila digunakan sebagai bahan makanan (media menggoreng) akan memicu meningkatnya kadar Low Density Lipoprotein (LDL) dalam darah sehingga berpotensi menyebabkan penyakit jantung coroner, kardiovaskuler, hipertensi dan kanker (Winarno, 1999). Proses penggumpalan (emulsi) minyak secara alami menyebabkan penyumbatan pada saluran air dan berdampak pada proses pencemaran lingkungan apabila minyak langsung dibuang begitu saja tanpa proses lebih lanjut. Dampak lain yang diakibatkan jika minyak jelantah langsung dibuang ke lingkungan yaitu menyebabkan tanah menjadi gersang dan tanaman akan sulit tumbuh.

Regenerasi minyak jelantah adalah salah satu upaya peningkatan kualitas minyak jelantah dengan cara menurunkan bilangan asam dan kadar asam lemak bebas. Berbagai metode telah dikembangkan dalam upaya penurunan kadar asam lemak bebas yang ada pada minyak jelantah seperti penggunaan zeolit alam aktif (Widayat, 2007), penggunaan tanah diatom (Winarni, Sunarto, \& Mantini, 2010), membran silikat dari abu sekam padi (Kalapathy \& Proctor, 2000), dan arang aktif (Aldila, Mahardika, Megiyo, \& Enggiwanto, 2017) (Mahardika, Aldila, Megiyo, \& Enggiwanto, 2017). Dari beberapa metode yang telah dikembangkan metode adsorbsi masih menjadi unggulan karena kemudahan dalam perolehan bahan baku, prosesnya yang sederhana, murah dan efisien. Salah satu adsorben yang sering digunakan dalam metode ini adalah karbon aktif karena dapat mengadsorbsi radikal bebas dan impuritas sisa-sisa penggorengan.

Tempurung ketapang merupakan salah satu biomassa yang begitu melimpah dan layak untuk dijadikan karbon aktif. Pemanfaatan karbon aktif dari tempurung ketapang sebagai adsorben pada peningkatan kualitas minyak jelantah dengan variasi temperatur pengadukan menghasilkan bahwa kondisi optimum tercapai pada variasi temperatur $70^{\circ} \mathrm{C}$ selama 30 menit dengan kadar asam lemak bebas $2,05 \%$, bilangan asam $1,64 \%$, dan massa jenis $0,86 \mathrm{gr} / \mathrm{mL}$ (Aldila, Mahardika, Megiyo, \& Enggiwanto, 2017). Sedangkan penggunaan ekstrak idingiding sebagai antioksidan pada peningkatan kualitas minyak jelantah menghasilkan kondisi optimum pada konsentrasi ekstrak 0,75\% dengan kadar asam lemak bebas 1,052\% dan bilangan asam 1,346\% (Mahardika, Aldila, Megiyo, \& Enggiwanto, 2017). Akan tetapi pada penelitian diatas belum mengkaji aspek pengaruh penambahan karbon aktif tempurung ketapang pada peningkatan kualitas minyak jelantah. Oleh karena itu penelitian ini akan mengkaji pengaruh variasi penambahan karbon aktif tempurung ketapang sebagai adsorben pada minyak jelantah. 


\section{Metode Penelitian}

\subsection{Alat dan Bahan}

Alat yang digunakan dalam penelitian ini yaitu, gelas ukur, beaker glass, cawan petri, mortar, tungku karbonisasi, furnace, $\mathrm{pH}$ meter digital, magnetik stirer, botol sampel, kertas saring, buret, pipet tetes, tabung erlenmeyer dan blender.

Bahan yang digunakan pada penelitian ini yaitu: tempurung ketapang, asam sulfat $\left(\mathrm{H}_{2} \mathrm{SO}_{4}\right)$, akuades, minyak jelantah, kertas saring, pucuk iding-iding, $n$-heksana, indikator PP, $\mathrm{NaOH}$ dan etanol.

\subsection{Tahapan Sintesis}

Tempurung ketapang yang diperoleh disekitar kampus Universitas Bangka Belitung dijemur dibawah terik sinar matahari hingga kering kurang lebih selama dua hari. Tahap berikutnya adalah proses karbonisasi dimana tempurung ketapang yang telah kering kemudian dibakar di dalam tungku hingga menjadi karbon (arang). Karbon yang diperoleh kemudian digerus dan diayak menggunakan ayakan ukuran 50 mesh. Selanjutnya karbon sebanyak 100 gram dicampurkan dengan aktivator asam sulfat $\left(\mathrm{H}_{2} \mathrm{SO}_{4}\right) 11 \%$ sebanyak $400 \mathrm{~mL}$ kemudian diaduk selama 30 menit. Setelah itu ditutup dan dibiarkan selama 1 hari. Karbon hasil perendaman kemudian dicuci menggunakan akuades hingga $\mathrm{pH}$-nya netral dan disaring menggunakan kertas saring hingga terbentuk prekursor karbon aktif. Prekursor karbon aktif selanjutnya dibakar dalam furnace pada suhu $650^{\circ} \mathrm{C}$ selama 2 jam. Untuk menghilangkan abu selama proses pembakaran, karbon aktif yang diperoleh kemudian dibilas dengan menggunakan aquades. Setelah itu untuk mengurangi kadar air, karbon aktif dipanaskan didalam oven pada suhu $80^{\circ} \mathrm{C}$ selama 3 jam. Karakterisasi karbon aktif yang digunakan meliputi kadar volatile matter, kadar abu dan analisa mikrostruktur.

Minyak jelantah yang digunakan dalam penelitian ini diperoleh dari limbah industri gorengan disekitar wilayah Pangkalpinang. Dari sampel minyak jelantah tersebut diambil 3 sampel dengan massa minyak masing - masing sampel 10 gram dan satu sampel minyak goreng kemasan yang digunakan sebagai pembanding (tanpa diberi perlakuan). Proses selanjutnya minyak ditambahkan dengan $5 \%$ pucuk iding - iding dengan variasi karbon aktif $5 \%, 7,5 \%$ dan 10\% kemudian dilakukan pengadukan menggunakan hot plate stirer selama 15 menit pada suhu $80^{\circ} \mathrm{C}$. Setelah itu sampel didiamkan selama 24 jam. Tahap berikutnya sampel disaring menggunakan kertas saring dan dilakukan pengujian kadar asam lemak bebas dan bilangan asam.

\subsection{Pengujian Sampel}

\subsubsection{Mikrostruktur Karbon Aktif}

Pengujian mikrostruktur karbon aktif tempurung ketapang menggunakan alat Scanning Electron Microscopy (SEM) merk Hitachi tipe: SU-3500. Pengujian ini bertujuan untuk menganalisa struktur permukaan yang meliputi distribusi dan estimasi ukuran pori karbon aktif.

\subsubsection{Kadar $\mathrm{Abu}$}

Sejumlah karbon aktif ditimbang kemudian dimasukkan ke dalam crucible yang telah diketahui massanya dan dimasukkan ke dalam furnace. Selama proses pemanasan digunakan rata-rata kenaikan suhu $1^{\circ} \mathrm{C}$ per 0,1 detik dan setelah mencapai suhu $650^{\circ} \mathrm{C}$ ditahan selama dua jam. Apabila seluruh karbon telah menjadi abu, sampel dimasukkan ke dalam desikator 
untuk proses pendinginan lalu ditimbang massanya. Kadar abu pada sampel dapat ditentukan menggunakan persamaan 1 (Aldila, Mahardika, Megiyo, \& Enggiwanto, 2017).

Keterangan:

$$
\text { Kadar Abu }=\frac{m_{a}}{m_{a c}} \times 100 \%
$$

$m_{a}=$ massa $a b u$

$$
m_{a c}=\text { massa karbon aktif awal }
$$

\subsubsection{Kadar Volatile Mater}

Karbon aktif tempurung ketapang dipanaskan selama 2 jam dengan suhu pemanasan $650^{\circ} \mathrm{C}$ dalam furnace. Setelah suhu tercapai karbon dibiarkan dingin dalam furnace dalam kondisi tidak berhubungan secara langsung dengan udara. Setelah dingin dimasukan kedalam desikator dan di timbang. Kadar volatile matter pada sampel dapat ditentukan menggunakan persamaan 2 (Aldila, Mahardika, Megiyo, \& Enggiwanto, 2017).

Keterangan:

$$
\text { Kadar Volatile Matter }=\frac{m_{i}-m_{f}}{m_{i}} \times 100 \%
$$

$m_{i}=$ massa karbon aktif awal

$$
m_{f}=\text { massa karbon aktif setelah dipanaskan }
$$

\subsubsection{Kadar Asam Lemak Bebas}

Sebanyak 1 gram sampel direaksikan dengan $25 \mathrm{ml}$ etanol 95\% hingga sampel terlarut. Indikator fenolftalein ditambahkan dalam sampel kemudian dititrasi dengan $\mathrm{KOH} 0,01 \mathrm{~N}$ sampai terbentuk warna merah muda tetap (tidak berubah selama 30 detik). Kadar asam lemak bebas yang terkandung dalam minyak dihitung dengan menggunakan persamaan 3 (Lempang, Fatimawali, \& Pelealu, 2016).

Keterangan:

$$
\text { Kadar asam lemak bebas }=\frac{\mathrm{Mx} \mathrm{Ax} \mathrm{N}}{10 \mathrm{G}} \times 100 \%
$$

$$
\begin{array}{ll}
\mathrm{M}=\text { berat molekul asam lemak, yaitu 263 } & \mathrm{A}=\text { volume } \mathrm{ml} \mathrm{KOH} \\
\mathrm{N}=\text { normalitas larutan } \mathrm{KOH} & \mathrm{G}=\text { berat sampel (gram) }
\end{array}
$$

\subsubsection{Bilangan Asam}

Pengujian bilangan asam dilakukan dengan cara mereaksikan 1 gram sampel dengan 10 $\mathrm{mL}$ alkohol 95\% netral dan dipanaskan selama 10 menit. Kemudian menambahkan indikator fenolftalein dan dititrasi dengan $\mathrm{KOH} 0,01 \mathrm{~N}$ hingga terbentuk warna merah muda yang tidak berubah selama 0,5 menit. Nilai bilangan asam dihitung dengan persamaan 4 (Lempang, Fatimawali, \& Pelealu, 2016).

$$
\% \text { Bilangan Asam }=\frac{A \times N ~ K O H ~ x ~ 56,1}{m} \times 100 \%
$$

Keterangan:
$\mathrm{A}=$ Volume larutan $\mathrm{KOH}$
$\mathrm{N}=$ Normalitas
$\mathrm{m}$ = massa sampel minyak (gram)

\section{Hasil dan Pembahasan}

Morfologi permukaan karbon aktif tempurung ketapang yang berhasil disintesis menggunakan aktivator asam sulfat dengan suhu aktivasi $650^{\circ} \mathrm{C}$ pada perbesaran $2000 \mathrm{kali}$ disajikan pada Gambar 1. 


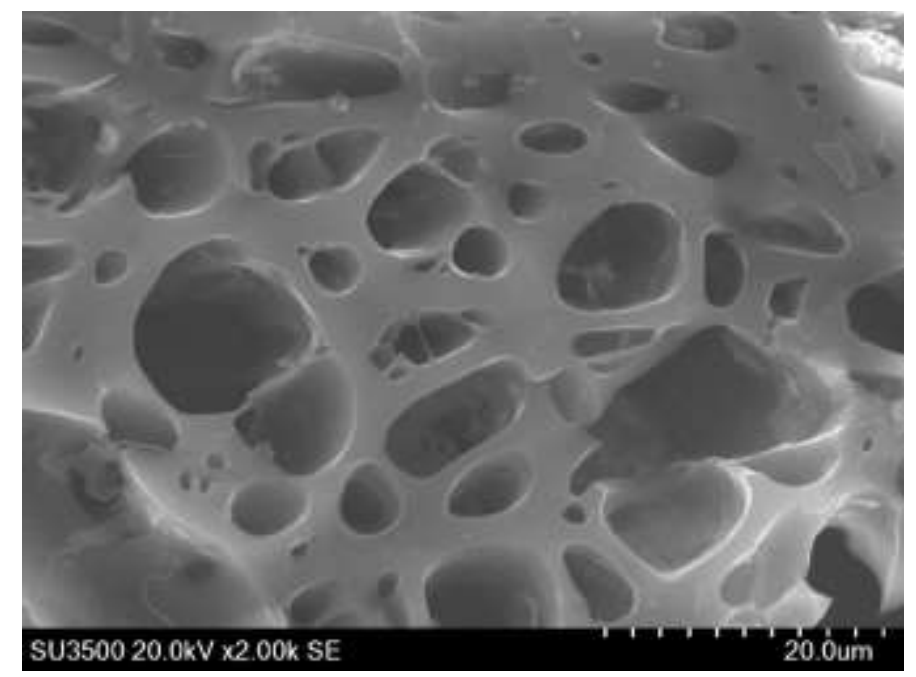

Gambar 1. Mikrostruktur karbon aktif ketapang

Berdasarkan Gambar 1. dapat diamati bahwa distribusi pori pada permukaan karbon aktif tempurung ketapang merata pada permukaan dengan ukuran dan kedalaman pori yang bervariatif. Dengan menggunakan aplikasi perangkat lunak ImageJ diperoleh ukuran pori ratarata sebesar $10 \mu \mathrm{m}$. Secara umum pori karbon aktif yang dihasilkan masuk dalam pori kategori dangkal. Kedalaman pori yang dangkal dapat mengakibatkan penurunan daya adsorbsi pada karbon aktif. Pori yang dangkal dapat disebabkan oleh beberapa aspek diantaranya karakteristik bahan baku, lama waktu aktivasi, dan kadar abu.

Pada dasarnya tempurung ketapang merupakan material komposit kompleks yang terbentuk dari polimer alam diantaranya selulosa, lignin dan hemiselulosa. Selama proses karbonisasi pada temperatur tinggi struktur polimer ini terdekomposisi dan terbebas dalam bentuk unsur non karbon seperti hidrogen, oksigen, dan nitrogen baik dalam bentuk cair (tar) maupun gas dan akan meninggalkan struktur padatan karbon dalam bentuk lapisan aromatis (Kwaghger, 2013). Pada proses aktivasi kimiawi reaksi antara karbon (arang) dengan asam sulfat menyebabkan terjadinya depolimerisasi, dehidrasi dan redistribusi unsur-unsur biopolimer serta berperan dalam proses konversi senyawa alifatik menjadi senyawa aromatik yang belum terbentuk selama proses karbonisasi sehingga menyebabkan kadar karbon terikat dalam arang akan meningkat.

Mekanisme dekomposisi ini didasari pada sifat asam sulfat yang bersifat korosif akan mendekomposisi unsur hemiselulosa dan lignin karena unsur selulosa lebih resisten terhadap asam. Asam ini akan menghidrolisis rantai glikosidik m-lignoselulosik dan memotong ikatan aril eter dalam lignin. Reaksi ini akan melibatkan transformasi kimia yang secara lebih jauh lagi didalamnya terdapat proses dehidrasi, degradasi dan kondensasi (Kwaghger, 2013). Jika selama proses reaksi diberikan perlakuan panas maka peningkatan temperatur reaksi menyebabkan terjadinya reaksi kondensasi aromatik molekul-molekul yang berdekatan yang mana akan menghasilkan produk berupa gas dari struktur hidro-aromatik pada arang yang terkarbonisasi sehingga dapat menurunkan kadar karbon yang dihasilkan.

Kadar volatile mater pada karbon aktif tempurung ketapang pada penelitian ini tergolong sangat tinggi sebesar $68,85 \%$. Tingginya kadar volatil matter ini disebabkan oleh hilangnya senyawa volatile seperti $\mathrm{CO}_{2}, \mathrm{CO}$ dan $\mathrm{H}_{2} \mathrm{O}$ (Pari,1999). Hal ini disebabkan lama waktu perendaman pada proses aktivasi kimia menyebabkan terjadinya dehidrasi secara intensif. Selain itu titik didih aktivator yang rendah menyebabkan aktivator dapat dengan mudah menguap selama proses aktivasi termal. Kenaikan temperatur dan lama waktu penahanan pada saat proses aktivasi termal menyebabkan laju reaksi $\mathrm{C}-\mathrm{H}_{2} \mathrm{SO}_{4}$ dan $\mathrm{C}-\mathrm{CO}_{2}$ meningkat. 
Sehingga hasilnya meningkatkan devolatilisasi (penghilangan senyawa volatil) yang menyebabkan proses pengembangan struktur pori yang masih belum sempurna pada arang serta meningkatkan jumlah pori yang terbentuk. Dengan demikian hasil proses ini akan menciptakan luas permukaan dan porositas yang lebih tinggi pada struktur karbon. Proses penghilangan abu dengan cara mencuci karbon aktif dengan menggunakan aqudes menyebabkan meningkatnya kadar air dalam karbon aktif. Kadar air ini dikurangi dengan cara dipanaskan dalam oven pada suhu $80^{\circ} \mathrm{C}$ selama 3 jam. Akan tetapi besarnya nilai kadar volatil meter mengindikasikan saat proses dehidrasi menggunakan oven terbukti bahwa kadar air masih relatif tinggi sehingga proses dehidrasi belum optimal.

Berdasarkan pada Persamaan 1, Kadar abu pada karbon aktif tempurung ketapang sebesar 7,3\%. Hasil ini menunjukkan bahwa jumlah abu/tar yang menutupi pori tidak terlalu banyak. Hal ini dapat diamati pada Gambar 1 bahwa kadar abu dalam pori tidak menutupi pori pada permukaan karbon aktif. Kandungan kadar abu meningkat seiring dengan peningkatan waktu perendaman dan suhu aktivasi. Selain itu titik didih dari aktivator yang rendah menyebabkan dengan mudah akan menguap meninggalakan prekursor karbon aktif dan prekursor menjadi kering. Dengan demikian kemungkinan untuk terjadinya pembakaran sempurna akan menghasilkan peningkatan kadar abu.

Minyak jelantah sebanyak 10 gram ditambahkan karbon aktif dengan berbagai variasi (5\%, 7,5\% dan $10 \%$ ) dan ditambahkan dengan 5\% ekstrak iding-iding. Ekstrak iding-iding yang digunakan mengandung senyawa flavonoid dan tanin yang merupakan senyawa golongan polifenol aktif yang bertindak sebagai antioksidan dalam minyak. Minyak tersebut direndam dalam campuran tersebut selama 24 jam yang selanjutnya dianalisis kadar asam lemak bebas dan nilai bilangan asam. Sampel ini selanjutnya disebut dengan renyak. Hasil analisis bilangan asam lemak bebas pada renyak dan minyak kemasan dapat dilihat pada Gambar 2 .

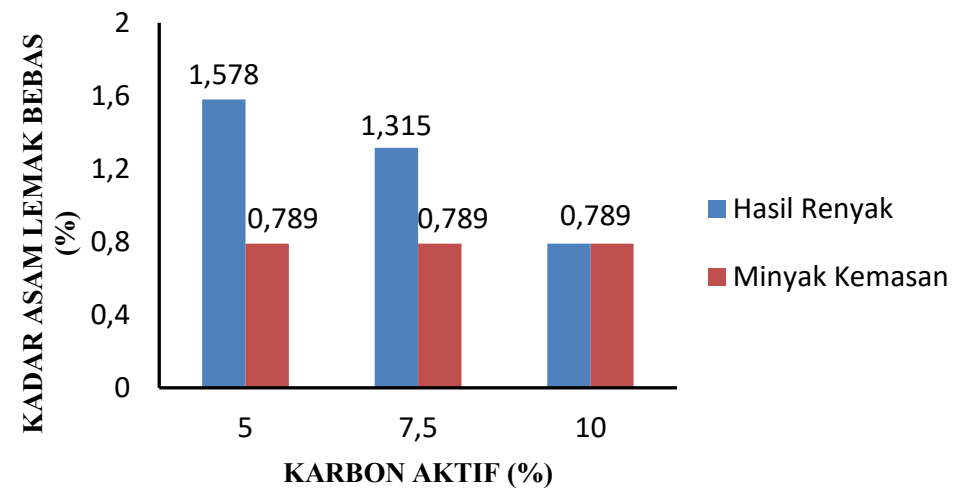

Gambar 2. Hasil analisis asam lemak bebas renyak dan minyak kemasan

Hasil pengamatan pada grafik pada Gambar 2 tersebut menunjukkan bahwa sampel renyak dengan menggunakan 10\% karbon aktif dan 5\% ekstrak iding-iding mempunyai kadar asam lemak bebas sama dengan minyak goreng kemasan yang masih baru. Sedangkan penggunaan karbon aktif 5\% dan 7,5 \% mempunyai kadar asam lemak bebas yang tinggi dibandingkan kadar asam lemak minyak goreng kemasan. Hal ini disebabkan karena pada sampel renyak mengandung kadar air yang tinggi sehingga mempercepat hidrolisis pada minyak goreng jelantah. Semakin sedikit penggunaan karbon aktif menyebabkan adsorbsi air dalam minyak tersebut kurang, sehingga kadar air yang masih tinggi menyebabkan terjadinya hidrolisis. Sebaliknya semakin banyak penggunaan karbon aktif maka kadar asam lemak semakin sedikit. Kadar asam lemak yang sedikit menunjukkan bahwa kualitas minyak semakin meningkat. Semakin besar penggunaan karbon aktif akan menyebabkan terjadinya penurunan 
asam lemak bebas. Penurunan kadar asam lemak disebabkan karena penyerapan air dan partikel koloid hasil penggorengan yang diserap oleh adsorben semakin banyak. Tetapi hasil uji kadar asam lemak bebas dari ketiga variasi karbon aktif tersebut kurang sesuai dengan syarat yang ditetapkan oleh SNI 01-3741-2002 yaitu > 0,30\% (b/b).

Berdasarkan hasil analisis bilangan asam pada masing-masing sampel dengan variasi karbon aktif $(5 \%, 7,5 \%$ dan 10\%) dan 5\% ekstrak iding-iding berturut-turut sebesar 1,6 \%, $1,2 \%$ dan $0,8 \%$. Sedangkan minyak goreng kemasan yang masih baru mempunyai persentase bilangan asam yaitu 0,8 \%. Hasil analisis bilangan asam renyak dan minyak kemasan dapat dilihat pada Gambar 3.

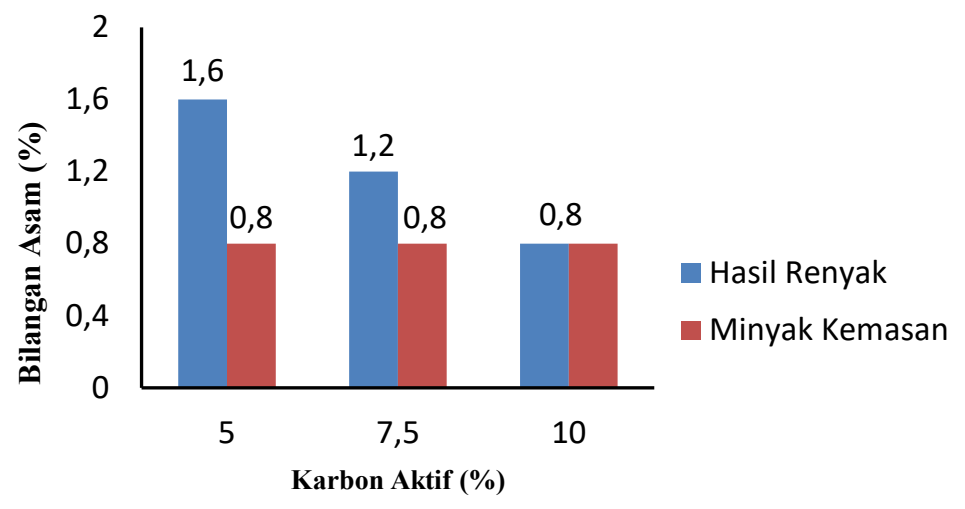

Gambar 3. Hasil analisis bilangan asam renyak dan minyak kemasan

Hasil pengamatan dari grafik pada Gambar 3 menunjukkan bahwa penggunaan 10\% karbon aktif dan 5\% ekstrak iding-iding mempunyai bilangan asam yang sama dengan bilangan asam minyak kemasan yang baru. Tetapi penggunaan $5 \%$ dan 7,5\% karbon aktif mempunyai bilangan asam yang lebih tinggi dibandingkan bilangan asam minyak kemasan. Hal ini karena semakin banyak karbon aktif maka bilangan asam menurun. Penurunan bilangan asam disebabkan karena penyerapan oleh adsorben semakin banyak. Bilangan asam yang rendah menunjukkan kualitas minyak yang bagus. Semakin banyak menggunakan karbon aktif semakin meningkat kualitas minyak hasil recovery. Hasil uji bilangan asam menunjukkan bahwa penambahan $10 \%$ karbon aktif mampu menurunkan kandungan bilangan asam sekitar $0,8 \%$. Bilangan asam tersebut mendekati standar mutu yang ditetapkan oleh SNI 01-3741-2002 yaitu $0,60 \%(b / b)$.

\section{Kesimpulan}

Berdasarkan hasil penelitian recovery minyak jelantah menggunakan ekstrak iding-iding dan karbon aktif dapat disimpulkan bahwa ekstrak iding-iding dan karbon aktif dapat digunakan untuk recovery minyak jelantah. Semakin banyak karbon aktif yang digunakan untuk recovery minyak maka dapat menurunkan kadar asam lemak bebas dan bilangan asam sehingga meningkatkan kulitas minyak jelantah. Penggunaan 10\% karbon aktif dan 5\% ekstrak iding-iding mempunyai kadar asam lemak bebas dan bilangan asam yang sama dengan minyak kemasan baru dan mendekati standar mutu SNI 01-3741-2002. 


\section{Saran}

Adapun saran untuk kemajuan dari penelitian ini adalah sebagai berikut :

Perlu dilakukan penelitian lanjutan yang berkaitan dengan karakteristik luas permukaan, kadar air, fasa dan komposisi kimia dari karbon aktif tempurung ketapang serta jenis aktivator karbon aktif.

\section{Daftar Pustaka}

Aldila, H., Mahardika, R. G., Megiyo, \& Enggiwanto, S. (2017). Variasi Temperatur Pengadukan Dalam Peningkatan Kualitas Minyak Jelantah Berbasis Arang Aktif Ketapang (Terminalia catappa) dan Ekstrak Iding-Iding (Stenochlaena palustris). Pangkalpinang: SNPPM FT 2017.

Djatmiko, B., \& Widjaja, A. P. (1985). Teknologi Minyak dan Lemak. Bogor: Departemen THP IPB.

Fauziah, N. (2009). Pembuatan Arang Aktif secara Langsung dari Kulit Acasia Mangium Wild dengan Aktivasi Fisika dan Aplikasinya sebagai Absorban. Bogor: IPB.

Halimah, S. N. (2016). Pembuatan dan Karakterisasi serta Uji Adsorbsi Karbon Aktif tempurung Kemiri (Aleurites moluccana) terhadap Metilen Biru. Bandar Lampung: Universitas Lampung.

Kalapathy, U., \& Proctor, A. (2000). A New Method for Free Fatty Acid Reduction in Frying Oil Using Silicate Films Produced from Rice Hull Ass. JAOCS, 593-598.

Kirk, R. E., \& Othmer, F. (1992). Encyclopedia of Chemical Technology. In K. S. Suslick (Ed.). New York: Interscience Publishing Incorporated.

Kristinah, H. D. (2009). Potensi Bentonit sebagai Penjernih Minyak Goreng Bekas. Universitas Diponegoro, Semarang.

Kwaghger, A. a. (2013). Optimization of conditions for the preparation of activated carbon from mango nuta using HCl. America Jurnal of Engineering Research ( AJER ), 02(07), 74- 85 .

Lempang, I. R., Fatimawali, \& Pelealu, N. (2016). Uji Kualitas Minyak Goreng Curah dan Minyak Goreng Kemasan di Manado. Pharmacon, 5, 155-161.

Mahardika, R. G., Aldila, H., Megiyo, \& Enggiwanto, S. (2017). Pengaruh Ekstrak IdingIding (Stenochlaena palustris) pada Proses Peningkatan Kualitas Minyak Jelantah Menggunakan Karbon Aktif Ketapang (Terminalia catappa). Pangkalpinang: SNPPM FT 2017.

Purnomo, S. E. (2010). Pembuatan Arang Aktif dari Kulit Biji Kopi Kering. Yogyakarta: Universitas islam Sunan Kalijaga.

Sembiring, M. T., \& Sinaga, T. S. (2003). Arang Aktif Pengenalan dan Proses Pembuatannya. Jurnal Kimia Digitized, 2-9.

Widayat. (2007). Studi Pengurangan Bilangan Asam, Bilangan Peroksida dan Absorbansi dalam Proses Pemurnian Minyak Goreng Bekas dengan Zeolit Alam Aktif. Jurnal Rekayasa Kimia dan Lingkungan, 6(1), 7-12.

Winarni, Sunarto, W., \& Mantini, S. (2010). Penetralan dan Adsorbsi Minyak Goreng Layak Konsumsi. Jurnal Sains dan Teknologi, 46-56. 
Winarno, F. G. (1999). Minyak Goreng dalam Menu Masyarakat. Bogor: Pusbangtepa IPB 